\title{
PENGARUH PENGGUNAAN MODEL COOPERATIVE LEARNING TIPE GROUP INVESTIGATION (GI) TERHADAP HASIL BELAJAR PRAKARYA DAN KEWIRAUSAHAAN (PKWU) SISWA KELAS X SEMESTER GENAP SMK NEGERI 1 METRO TP 2015-2016
}

\author{
Fajar Jefri Irawan ${ }^{1)}$ Ningrum ${ }^{2)}$ \\ Pendidikan Ekonomi FKIP Universitas Muhammadiyah Metro \\ fajar.jefri@gmail.com\&ningrum@gmail.com
}

\begin{abstract}
Abstrak
Metode cooperative learning tipe group investigation merupakan model pembelajaran kooperatif yang melibatkan siswa secara maksimal dalam kegiatan pembelajaran mulai dari merencanakan topik-topik yang akan dipelajari, bagaimana melaksanakan investigasinya, hingga melakukan presentasi kelompok dan evaluasi. Dalam Group Investigation tersebut siswa dibagi kedalam 6 kelompok yang setiap kelompok terdiri dari 4 siswa, setiap kelompok memilih topik yang sisajikan kemudian membagi topik-topik tersebut untuk dikerjakan oleh masing-masing kelompok. Kemudian menggabungkan hasil temuan tiap individu menjadi laporan kelompok, untuk selanjutnya setiap kelompok menyajikan hasil kerja dalam suatu diskusi kelas. Adapun yang menjadi masalah dalam penelitian ini yaitu " Masih banyak siswa yang belum tuntas hasil belajar Prakarya dan Kewirausahaan (PKWU) kelas X Semester Genap SMK Negeri 1 Metro Tahun Pelajaran 2015/2016.”. Dari masalah tersebut maka rumusan masalahnya adalah "Apakah ada pengaruh penggunaan model Coperative Learning Tipe Group Investigation (GI) terhadap hasil belajar prakarya dan kewirausahaan (PKWU) siswa kelas X semester genap SMK Negeri 1 Metro tahun pelajaran 2015/2016?". Tujuan penelitian ini adalah "untuk mengetahui pengaruh penggunaan model Cooperative Learning Tipe Group Investigation terhadap hasil belajar Prakarya dan Kewirausahaan (PKWU) siswa kelas X Semester Genap SMK Negeri 1 Metro tahun pelajaran 2015/2016". Berdasarkan hasil penelitian tersebut maka hipotesis ditermia, sebab $t_{\text {hitung }}\left(t_{o}\right)$ dalam analisis data dapat diketahui bahwa analisis perhitungan nilai tersebut $t_{\text {hitung }}$ $>t_{\text {tabel }}$. Pada taraf signifikan 5\% yaitu 10,27 > 1,72 yaitu $t_{\text {hitung }}$ lebih besar 8,48 dari $t_{\text {tabel }}$ Demikian menunjukan bahwa model Cooperative Learning tipe Group Investigation mempunyai pengaruh yang positif terhadap hasil belajar Prakarya dan Kewirausahaan (PKWU) siswa kelas X Semester Genap SMK Negeri 1 Metro tahun pelajaran 2015/2016.

Kata kunci: Cooperative Learning Tipe Group Investigation(Gi), Hasil Belajar
\end{abstract}

\section{PENDAHULUAN}

Perkembangan Ilmu Pengetahuan dan Teknologi (IPTEK) diera globalisasi sesuai Sumber Daya Manusia (SDM) yang berkuailitas.
Dengan begitu perkembangan IPTEK yang ada dapat dikuasai, dimanfaatkan semaksimal mungkin dan dapat di kembangkan menjadi lebih baik. Pendidikan adalah usaha sadar dan 
terencana untuk mewujudkan suasana belajar dan proses pembelajaran agar peserta didik secara aktif mengembangkan potensi dirinya untuk memiliki kekuatan spritual keagamaan, pengendalian diri, kepribadian, kecerdasan akhlak mulia, serta keterampilan yang diperlukan dirinya, masyarakat, bangsa, dan Negara. Pendidikan nasional adalah pendidikan yang berdasarkan pancasila dan Undang-Undang Dasar Negara Republik Indonesia Tahun 1945 yang berakar pada nilai-nilai agama, kebudayaan nasional Indonesia dan tetap pada tuntunan perubahan zaman.

Peningkatan kualitas sumber daya manusia merupakan salah satu penekanan dari tujuan pendidikan, seperti yang tertuang dalam Undang Undang No. 20 Tahun 2003 tentang tujuan Pendidikan Nasional Bab II Pasal 3 yang berbunyi:

Pendidikan Nasional bertujuan mengembangkan kemampuan dan membentuk watak serta peradaban bangsa yang bermartabat dalam rangka mencerdaskan bangsa, bertujuan untuk berkembangnya potensi peserta didik agar menjadi manusia yang beriman dan bertakwa kepada Tuhan YME, berakhlak mulia, sehat, berilmu, cakap, kreatif, mandiri dan menjadi warga negara yang demokratis serta bertanggung jawab.

Berbagai usaha telah dilakukan Dapartemen Pendidikan Nasional untuk memperbaiki mutu pendidikan nasional, agar tercapai tujuan secara optimal. Salah satunya yaitu penyempurnaan kurikulum. Penyempurnaan kurikulum adalah usaha menyesuaikan kurikulum dengan perkembangan ilmu pengetahuan dan teknologi, serta tuntutan kebutuhan masyarakat untuk mendapatkan proporsi yang tepat antara tujuan yang ingin dicapai dengan beban belajar, potensi siswa, dan keadaan lingkungan serta sarana pendukungnya di samping juga untuk memperoleh kebenaran substansi materi pelajaran dan kesesuaian dengan tingkat perkembangan siswa.

\section{KAJIAN PUSTAKA}

\section{Model Cooperative Learning Tipe Group Investigation}

Slavin (dalam Rusman, 2012:221) menyatakan bahwa:

"Tipe Group Investigation mengarah pada kegiatan perolehan, analisis, dan sintesis informal dalam upaya untuk memecahkan masalah".

Menurut Mafune (dalam Rusman, 2012:222) berpendapat model cooperative learning tipe group investigation dapat dipakai guru untuk mengembangkan kreativitas siswa, baik secara perorangan maupun kelompok. model Cooperative Learning Tipe Group Investigation dapat membantu siswa mengikuti pembelajaran dan berorientasi menuju pembentukan manusia sosial. 
Berdasarkan pada pendapat para ahli, maka dapat disimpulkan bahwa model Cooperative Learning Tipe Group Investigation merupakan model pembelajaran kooperatif yang melibatkan siswa secara maksimal dalam kegiatan pembelajaran mulai dari merencanakan topik-topik yang akan dipelajari, bagaimana melaksanakan investigasinya, hingga melakukan presentasi kelompok dan evaluasi. Model ini menekankan pada partisipasi dan aktivitas siswa untuk mencari sendiri materi (informasi) pelajaran yang akan dipelajari melalui bahan-bahan yang tersedia, misalnya dari buku pelajaran atau siswa dapat mencari melalui internet.

Tahap-Tahap Pelaksanaan Group Investigation

Implementasi Cooperative Learning Tipe Group Investigation dalam pembelajaran menurut Slavin (2010:218) secara umum dibagi menjadi enam tahap yaitu:

a. Mengidentifiksi topik dan mengorganisasikan siswa kedalam kelompok

b. Merencanakan tugas yang akan dipelajari

c. Melaksanakan investigasi

d. Menyiapkan laporan akhir

e. Mempresentasikan laporan akhir

f. Evaluasi

Menurut Rusman (2012:223) asumsi yang digunakan sebagai acuan dalam pengembangan model Cooperative Learning Tipe Group Investigation diantaranya:

a. Tahap pemecahan masalah
Tahap pemecahan masalah berkenaan dengan proses menjawab pertanyaan yang telah dirumuskan. Masing-masing kelompok fokus pada subtopik yang menjadi bagian dari kelompoknya. Selanjutnya bagaimana masing-masing kelompok melakukan upaya untuk mencari pemecahan dari masalah yang ada dalam kelompoknya.

b. Tahap pengelolaan kelas

Tahap pengelolaan kelas berkenaan dengan proses menjawab pertanyaan, informasi apa saja yang diperlukan, bagaimana mengorganisasikan kelompok untuk memperoleh informasi itu. Pada tahap ini masing-masing kelompok melakukan perencanaan kelompok yang berkaitan dengan bagaimana cara menyelesaikan masalah yang ada dalam kelompoknya, kemudian informasi apasaja yang akan digunakan dimana informasi tersebut dapat diperoleh dilingkungan sekitar siswa.

c. Tahap pemaknaan secara perorangan

Tahap pemaknaan secara perorangan berkenaan dengan proses pengkajian bagaimana kelompok menghayati kesimpulan yang dibuatnya, dan apayang membedakan seseorang sebagai hasil dari mengikuti proses tersebut. Setelah memperoleh informasi dari berbagai sumber langkah selanjutnya adalah melakukan 
diskusi, menganalisis dan menyimpulkan.

Berdasarkan pendapat yang telah dipaparkan tersebut dapat disimpulkan bahwa tahapan-tahapan dalam pelaksanaan Cooperative Learning Tipe Group Investigation merupakan model pembelajaran yang membuat siswa dapat yaitu:

1. Membangun pengetahuannya sendiri melalui belajar dalam kelompok.

2. Sedangkan guru hanya sebagai fasilitator dan membimbing siswanya dalam pengetahuan yang diperoleh siswa untuk menjadi pembelajaran yang lebih bermakna.

3. Siswa dapat memperoleh pengalaman yang lebih melalui proses belajarnya dari pada siswa yang belajar secara individual.

Kelebihan dan Kekurangan Group Investigation

Kelebihan dan kekurangan selalu terdapat dalam setiap model, strategi, dan metode pembelajaran. Namuun, kelebihan dan kekurangan tersebut hendaknya menjadi referensi untuk penekanan-penekanan terhadap hal yang positif dan meminimalisir kelemahan-kelemahannya dalam pelaksanaan pembelajaran.

Adapun menurut Setiawan (2006:9) kelebihan model Cooperative Learning Tipe Group Investigation adalah sebagai berikut.

a) Secara Pribadi dalam proses belajarnya dapat bekerja secara bebas; memberi semangat untuk berinisiatif, kreatif, dan aktif; rasa percaya diri dapat lebih meningkat; dapat belajar untuk memecahkan, menangani suatu masalah.

b) Secara sosial meningkatkan belajar bekerja sama; belajar berkomunikasi baik dengan teman sendiri maupun guru; belajar berkomunikasi yang baik secara sistematis; belajar menghargai pendapat orang lain; meningkatkan partisipasi dalam membuat suatu keputusan.

c) Secara akademis siswa terlatih untuk mempertanggung jawabkan jawaban yang diberikan; bekerja secara sistematis; mengembangkan dan melatih keterampilan; merencanakan dan mengorganisasikan pekerjaannya; mengecek kebenaran jawaban yang mereka buat; selalu berfikir tentang cara atau strategi yang digunakan sehingga didapat suatu kesimpulan yang berlaku umum. Kekurangan model Cooperative Learning Tipe Group Investigation menurut Setiawan (2006: 9), yaitu:
a) Sedikitnya materi yang tersampaikan pada satu kali pertemuan.
b) Sulitnya memberikan penilaian secara personal.
c) Tidak semua topik cocok dengan model pembelajaran group investigation.
d) Diskusi kelompok biasanya berjalan kurang efektif.
e) Siswa yang tidak tuntas memahami materi prasyarat akan mengalami kesulitan saat menggunakan model ini.




\begin{abstract}
Model Group Investigation memiliki kelebihan mampu meningkatkan keaktifan dan kreatifitas dalam belajar, kerjasama tim dan untuk mempertanggung jawabkan jawaban yang diberikan. Sedangkan kekuranganya adalah diskusi kelompok kurang efektif karena materi kurang cocok dengan model Group Investigation.
\end{abstract}

\section{Pengertian hasil belajar}

Hasil belajar merupakan suatu hal yang diperoleh siswa setelah mengikuti kegiatan proses pembelajaran berdasarkan kriterria tertentu dalam pengukuran pencapaian tujuan pembelajaran itu sendiri yang dapat memberikan perubahan tingkah laku baik pengetahuan, pemahaman, sikap dan keterampilan siswa sehingga menjadi lebih baik dari pada sebelumnya.

Sebagaimana yang dikemukankan Kunandar (2008:39) mengatakan bahwa; Hasil belajar adalah perubahan tingkah laku subyek yang meliputi kemampuan kognitif, afektif, dan psikomotorik dalam situasi tertentu berkat pengalamannya berulang-ulang. Pendapat tersebut didukung oleh Sudjana (2002:3) yang berpendapat bahwa; Hasil belajar adalah perubahan tingkah laku yang mencakup bidang kognitif, afektif, dan psikomotor yang dimiliki siswa setelah menerima pengalaman belajarnya.

Menurut Karwono dan Mularsih (2010:2) mengungkapkan bahwa hasil belajar adalah perubahan seseorang dikatakan sudah belajar apabila perilakunya menunjukkan perubahan, dari awalnya tidak tahu menjadi tahu, dari tidak mampu menjadi mampu, dari tidak terampil menjadi terampil.

Berdasarkan pendapat para ahli tersebut dapat disimpulakan bahwa hasil belajar yang dimaksudkan adalah hasil yang dicapai oleh siswa setelah melakukan proses pembelajaran. Hasil belajar tersebut dapat berupa pengetahuan dalam penguasaan sejumlah materi pelajaran, dan dapat pula disimbolkan dengan grade atau skor. Pada akhir proses pembelajaran, dilakukan evaluasi tes untuk melihat hasil belajar siswa.

\section{METODE PENELITIAN}

Penelitian yang akan dilakukan dalam penelitian ini adalah bentuk dari salah satu penelitian yang bersifat kuantitatif yang bertujuan untuk meningkatkan hasil belajar prakarya dan kewirausahaan pada siswa. Jenis penelitian yang akan dilakukan adalah eksperimen menggunakan dengan model Cooperative Learning Tipe Group Investigation. Metode eksperimen yang akan digunakan yaitu Quasi Exsperimental Design jenis Control Group Pre-test Post-test. Dalam desain ini terdapat kelas eksperimen dan kelas kontrol yang akan terlihat perbedaan pencapaian antara kedua kelas tersebut. Penentuan kelas dipilih menggunakan teknik Cluster Random Sampling. Adapun proses pelaksanaannya nanti akan diberikan pendalaman teori terlebih 
dahulu, kemudian diskusi dengan menggunakan model Cooperative Learning Tipe Group Investigation agar siswa dapat lebih memahami materi yang akan disampaikan.

Pelaksanaan pre-test baik kelas eksperimen maupun kelas kontrol dilakukan sebelum pelaksanaan proses pembelajaran. Setelah itu akan dilaksanakan proses pembelajaran baik pada kelas eksperimen maupun kelas kontrol. Pembelajaran pada kelas eksperimen dilakukan dengan menggunakan Cooperative Learning tipe Group Investigationsi. sedangkan kelas kontrol diberikan perlakuan yang beda yakni dengan menggunakan metode latihan yang biasa digunakan oleh guru dalam pembelajaran dikelas. Selanjutnya akan dilakukan post-test pada kelas eksperimen dan kelas kontrol untuk mengetahui hasil belajar dari proses pembelajaran.

Proses pembelajaran dilaksanakan dengan tatap muka sebanyak 4 kali baik pada kelas eksperimen maupun kelas kontrol, perincian waktu satu kali pertemuan untuk pre-test, satu kali pertemuan untuk menyampaikan materi pelajaran, satu kali pertemuan untuk penerapan model Cooperative Learning Tipe Group Investigation, dan satu kali untuk post-test.

Penelitian ini populasinya adalah seluruh siswa kelas X SMK Negeri 1 Metro yang sebanyak 12 kelas dengan jumlah 378 siswa. Untuk sampel penelitian ini peneliti mengambil sampel dengan menggunakan cluster random sampling yaitu suatu teknik pengambilan sampel dimana dilakukan pengundian terhadap sejumlah kelompok atau menuliskan satu nomer untuk setiap kelas, yaitu kelas Xa1, Xa2, Xa3, Xp1, Xp2, Xp3, Xak1, Xak2, Xap1, Xap2, Xjb1 dan Xjb2. Dari hasil pengundian ini yang menjadi sampel penelitian terpilih kelas Xak1 yang berjumlah 32 siswa dan yang menjadi kelas kontrol adalah kelas Xak2 yang berjumlah 32 siswa.

\section{PEMBAHASAN HASIL PENELITIAN}

Berdasarkan hasil yang diperoleh dari penelitian di SMK Negeri 1 Metro yaitu hasil pre-test-post-test terlihat bahwa pada kelas eksperimen diperoleh rata-rata hasil pre-test yang tuntas yaitu $12,5 \%$ (4 siswa) dan ratarata hasil post-test yang tuntas yaitu $87,5 \%$ (28 siswa)sedangkan kelas kontrol rata-rata hasil pre-test yaitu 31,25 dan rata-rata hasil pos-test 62,5 Hal tersebut menunjukkan bahwa ada pengaruh terhadap kemampuan kognitif siswa yang pembelajarannnya menggunakan model Cooperative Learning tipe Group Investigationpada siswa kelas Xak 1SMK Negeri 1 Metro Tahun Pelajaran 2015/2016 dan kemampuan kognitif siswa yang menggunakan model Cooperative Learning tipe Group Investigationlebih tinggi dari kemampuan kognitif siswa yang menggunakan pembelajaran konvensional.

Hal tersebut dapat dilihat dari tes akhir dengan 20 soal pilihan ganda 
sehingga didapat untuk kelas eksperimen yang mencapai KKM berjumlah 22 siswa sedangkan kelas kontrol yang mencapai KKM berjumlah 10 siswa. Hal ini menunjukkan bahwa peningkatan pada kelas eksperimen dan kelas kontrol berbeda, dari hasil uji tes formatif diperoleh bahwa peningkatan pada kelas eksperimen lebih tinggi dari peningkatan pada kelas kontrol.

\section{KESIMPULAN}

Berdasarkan penelitian yang
dilakukan oleh penulis dapat
disimpulkan bahwa hasil analisis data
dalam penelitian dari 32 siswa yang
diberikan perlakuan (treatment)
Pembejaran aktifitas belajar yang
menggunakan model Cooperative
Learning tipe Group Investigation,
Siswa yang hasil belajar Prakarya dan Kewirausahaan termasuk dalam kategori tuntas sebanyak 22 siswa atau sebesar 62,5, sedangkan siswa yang hasil belajar Prakarya dan Kewirausahaan termasuk dalam kategori belum tuntas sebanyak 10 siswa atau sebesar 37,5. Sedangkan yang tidak diberikan (treatment) yang berjumlah 32 siswa hasil belajar Prakarya dan Kewirausahaan termasuk dalam kategori tuntas sebanyak 4 siswa atau sebesar 12,5, sedangkan siswa yang hasil belajar Prakarya dan Kewirausahaan termasuk dalam kategori belum tuntas sebanyak 28 siswa atau sebesar 87,5. Maka dengan adanya temuan-temuan hasil belajar yang meningkat setelah diberikan perlakuan atau treatment menggunakan model Cooperative Learning tipe Group Investigation dalam proses pembelajaran yang telah dianalisis dan diuji hipotesisnya.

Pada pengujian dengan menggunakan rumus Regresi Linier Sederhana diperoleh $\mathrm{a}=47,8434 \mathrm{~b}=$ 0,4337 sehingga dengan demikian $\hat{Y}=$ $a+b X$, adalah $\mathrm{Y}=47,8434+0,4337$ $\mathrm{X}$. Kemudian, dari hasil analisis yang dilakukan maka terbukti bahwa ada pengaruh yang positif penggunaan media microsoft powerpoint terhdadap hasil belajar siswa SMK Negeri 1 Metro. Hal ini dibuktikan dengan penghitungan analisis data dapat diketahui bahwa nilai tersebut $t_{\text {hitung }}>$ $\mathrm{t}_{\text {tabel}}$, dan terlihat bahwa pada taraf signifikan $5 \%$ yaitu 3,61>1,70. Dan pada taraf signifikan $1 \%$ yaitu 3,61 > 2,46, yang dapat dilihat pada daftar $\mathrm{G}$ tabel statistik. Dengan demikian maka hipotesis diterima.

Dari kesimpulan yang penulis uraikan di atas, dan untuk perbaikan proses pembelajaran Prakarya dan kewirausaan itu sendiri, maka sesuai dengan hasil penelitian yang telah penulis laksanakan maka penulis akan menyampaikan saran-saran sebagai berikut:

1. Untuk meningkatkan hasil belajar diharapkan guru menjadi fasilitator dan motivator, sehingga siswa menjadi lebih aktif dalam proses pembelajaran dan 
penerapan model Cooperative tipe Group Investigation diharapkan bisa diterapkan sehingga siswa dapat lebih semangat dalam belajar dan tentunya dapat melatih agar siswa sama dengan baik.

2. Diharapkan siswa dapat lebih aktif dalam proses pembelajaran terutama dalam penerapan model Cooperative khususnya tipe Garoup Investigation. Tentunya dengan cara seperti ini, akan melatih siswa untuk bekerja sama antar kelompok dan dapat memecahkan masalah yang diberikan. Dengan begitu proses pembelajaran lebih inovatif dan selalu mengalami pembaharuan.

3. Untuk meningkatkan hasil belajar diharapkan Sekolah dapat meberikan fasilitas atau sarana dan prasarana yang memadai agar pendidik maupun siswa dapat lebih bersemangat dan nyaman ketika proses pembelajaran berlangsung.

Dengan tiga hal tersebut di atas mudah-mudahan dapat bermanfaat dengan baik untuk meningkatkan hasil belajar siswa dalam proses pembelajaran.

\section{DAFTAR PUSTAKA}

UU No. 20. (2003). Pengertian Pendidikan. Jakarta: Direktorat Menengah Kejuruan.
Rusman. (2012). Model-model pembelajaran. Depok. PT Rajagrafindo persada.

Robert. E Slavin. (2010). Cooperative Learning Teori, Riset dan Pratk. Bandung: Nusa Media

Setiawan. (2006). Model Pembelajaran Matematika Dengan Pendekatan Investigasi. Yogyakarta: Depdinas PPPG Matematika

Kunandar. (2008). Langkah Mudah Penelitian Tindakan Kelas Sebagai Pengembangan Profesi Guru.Jakarta: PT. Raja Grafindo Persada

Sudjana. (2002). Metode Statistika. Bandung: Tarsito.

Karwono \& Heni Mularsih 2010. Belajar dan Pembelajaran serta Pemenfaatan Sumber Belajar. Cerdas Jaya. Ciputat. 